M. Catalano, A. Bloise, D. Miriello, C. Apollaro, T. Critelli, F. Muto, E. Cazzanelli, and E. Barrese - The mineralogical study of the Grotta Inferiore di Sant'Angelo (southern Italy). Journal of Cave and Karst Studies, v. 76, no. 1, p. 51-61. DOI: 10.4311/2012ES0284

\title{
THE MINERALOGICAL STUDY OF THE GROTTA INFERIORE DI SANT'ANGELO (SOUTHERN ITALY)
}

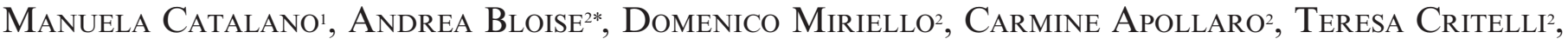 \\ Francesco $\mathrm{Muto}^{2}$, Enzo Cazzanelli' ${ }^{1}$ and Eugenio Barrese ${ }^{2}$
}

\begin{abstract}
In the present work, thirteen samples collected from the Grotta Inferiore di Sant'Angelo near the town of Cassano allo Jonio (Calabria region, southern Italy) were analyzed for their mineralogy. The Grotta Inferiore di Sant'Angelo is made up of subhorizontal, interlinked galleries between 400 and 450 meters above sea level. The floor is littered with deposits such as bat-guano, gypsum, and many speleothems that also cover the walls. The samples were identified and characterized by X-ray powder diffraction, scanning electron microscopy with energy dispersive spectrometer, microthermometry, and micro-Raman spectroscopy. The ten primary minerals identified in this study belong to six different groups: carbonate, sulfate, apatite, oxide and hydroxide, halide, and silicate. Clay minerals and eight other detrital minerals were also found: enstatite, rutile, magnesite, pyrite, chrysotile, quartz, dolomite, and chlorite. Characterization of cave minerals could be useful to improve the knowledge of the relation between them and the lithology of the host rocks.
\end{abstract}

\section{INTRODUCTION}

Natural caves may give rise to complex minerogenetic processes controlled by particular conditions that change from one cave to the next (Hill and Forti, 1997). In-depth characterization of cave minerals may be the first step toward understanding the genetic processes of cave minerals and chemical deposits. However, to reach this ambitious goal, various aspects of the cave must be investigated, such as host rocks, cave sediments, and circulating fluids (Hill and Forti, 1997; Frau et al., 1998; Lattanzi et al., 1998). Some very different minerogenetical mechanisms may induce the deposition of crystalline and amorphous phases that are stable as long as environmental conditions remain constant. These phases may easily change if genetic conditions change (Benedetto et al., 1998; Forti et al., 1999, 2000, 2001). For this reason, caves where environmental conditions have changed are good environments in which various types of mineral phases can grow.

The presence of hypogenic caves (Galdenzi, 1997) made the karst area of Monte San Marco (Cassano allo Ionio) (Fig. 1) an ideal site in which to study cave mineralogy. The complex of the Sant'Angelo caves is the largest, and it is made up of three caves: Grotta Superiore di Sant'Angelo, Grotta Inferiore di Sant'Angelo, and Grotta Sopra la Grotte di Sant'Angelo.

The Grotta Inferiore di Sant'Angelo was only explored a few decades ago, in 1951, by Orofino (1965). It was not until 1977-1979 that it was studied systematically by the Commissione Grotte Eugenio Boegan (Gasparo, 1979; Larocca, 1991). The cave extends about 1325 meters and is linked to other caves with natural entrances at various elevations on the slopes of Monte San Marco. It has been explored over the years and has revealed evidence of human habitation since the Neolithic and Bronze Ages (Tinè, 1964a, b; Malone, 2003).

Morphologically, the Grotta Inferiore di Sant'Angelo is made up of sub-horizontal, interlinked galleries between 400 and 450 meters above sea level. The floor is littered with deposits of heterogeneous alluvial material and filled with guano deposits, gypsum that was partially quarried in the past, and many speleothems that also cover the walls (Gasparo, 1979; Larocca, 1991). In contrast to the large number of papers on the speleological and geomorphological characterization of the Sant'Angelo caves (Gasparo, 1979; Larocca, 1991; Galdenzi, 1997), no previous papers report in detail the minerals of the Grotta Inferiore di Sant'Angelo. So the aim of this paper was the characterizations of the minerals collected in the cave.

\section{Geological Setting}

The study area is in the Cassano structural high, in particular in the dolomitic and calcareous Meso-Cenozoic successions outcropping in Monte San Marco (Fig. 1). The carbonate rocks are topped by alternating grey and varicolored shale and phyllite of Cretaceous age. The metamorphic rocks are overlapped by a thick clastic terrigenous succession of Pliocene-Pleistocene age (Fig. 2) made up of conglomerates, sand, and thick bodies of clay and silt. Knowledge of the geologic evolution of the Cassano structural high has been improved by data on the Quaternary tectonic and morphostructural phase. In

\footnotetext{
* Corresponding Author: andrea.bloise@unical.it

${ }^{1}$ Dipartimento di Fisica, Università degli Studi della Calabria, Ponte P. Bucci cubo 31C, 87036 Arcavacata di Rende (CS), Italy

${ }^{2}$ Dipartimento di Biologia, Ecologia e Scienze della Terra, Università degli Studi della Calabria, Ponte P. Bucci cubo 15B, 87036 Arcavacata di Rende (CS), Italy
} 


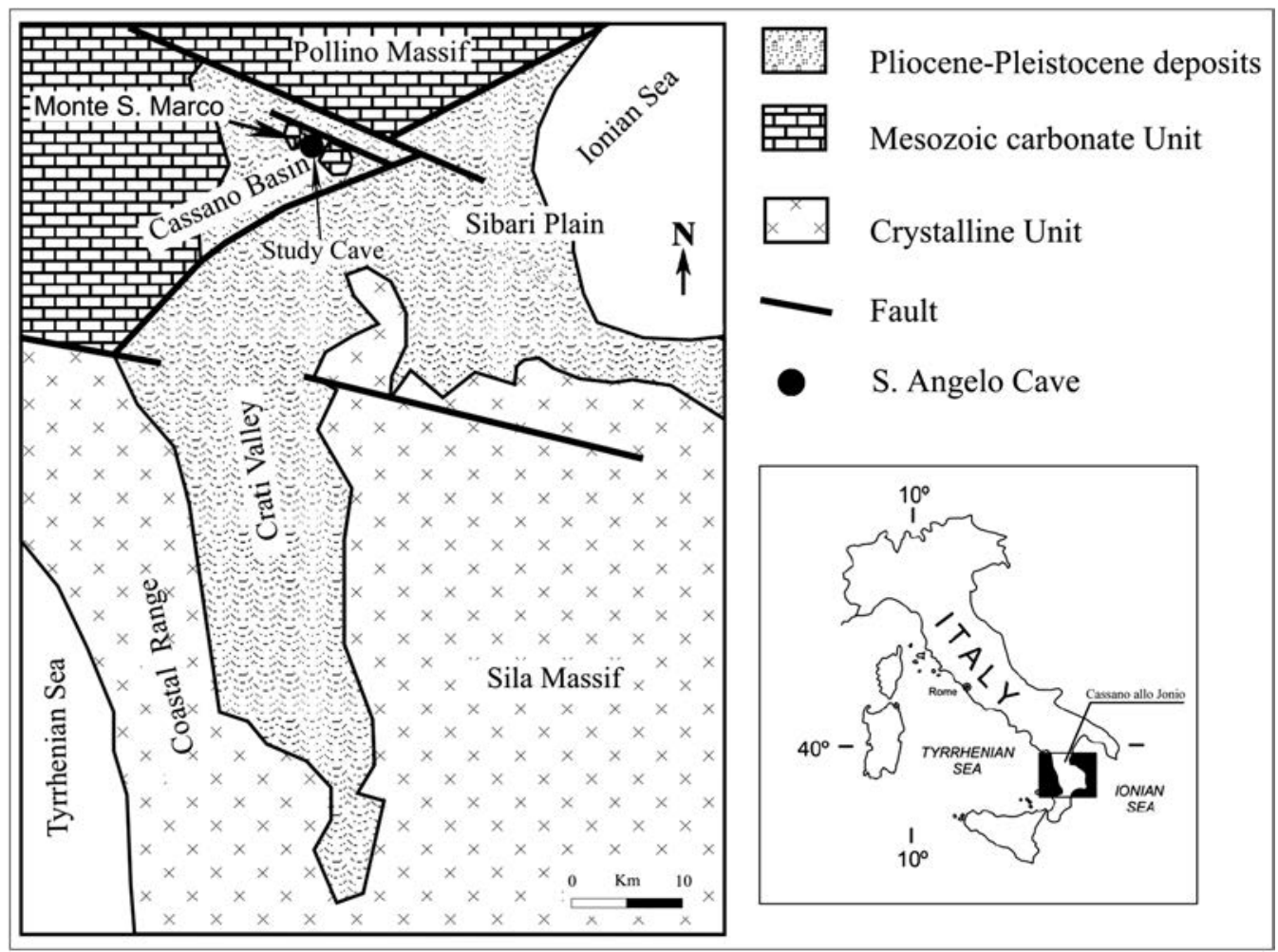

Figure 1. Location of Grotta Inferiore di Sant'Angelo and geological map of the area.

particular, the area is characterized by large trascurrent and normal fault systems exposing the Mesozoic and Quaternary terrains. The fracture and joint systems in Monte San Marco are linked to the main northeast- and northwest-oriented fault systems (Schiattarella, 1998; Spina et al., 2009). Along the major fault, a large, deep cave system developed, probably during the Pleistocene uplift of the area (Fig. 2a). The first subsurface cavities were formed by dissolution of the limestone related to the rising of $\mathrm{H}_{2} \mathrm{~S}$-rich water within the limestone (Fig. 2a). Tectonic activity in the major fault was responsible for exhumation of carbonate rocks and gave rise to aquifer circulation. Thermal springs represent the subsurface upwelling of the Sibari thermal system and sulfate waters (Apollaro et al., 2012). The chemical characteristics of the waters suggest that the oxidation of $\mathrm{H}_{2} \mathrm{~S}$ to sulfuric acid favored by the mixing between thermal water $\left(\mathrm{Ca}-\mathrm{SO}_{4}\right.$ to $\mathrm{Ca}-\mathrm{SO}_{4}-\mathrm{HCO}_{3}$ in composition) and fresh water $\left(\mathrm{Ca}-\mathrm{HCO}_{3}\right.$ to $\mathrm{Ca}-\mathrm{Mg}-\mathrm{HCO}_{3}$ (Apollaro et al., 2012) infiltrating along the major fault was the main source of aggressiveness and dissolution of limestone. The progressive fall in the piezometric level is due to gradual exhumation of the top and lateral aquicludes, represented by shale and phyllite displaced by major faults (Galdenzi, 1997) (Fig. 2b). During this stage, sulfate waters saturated carbonate rocks and caves, enabling the precipitation and growth of sulfate crystals. Unsaturated conditions were progressively established, due to erosion and exhumation of the hanging wall, with a consequent fall in the level of the thermal water that today lies at 230 to $270 \mathrm{~m}$ below the cave entrance (Fig. 2c).

\section{Sampling And Analytical Techniques}

Thirteen samples were collected along the main accessible galleries and rooms of the Grotta Inferiore di Sant'Angelo. Figure 3 is a map of the cave that shows the locations where the primary minerals were found in the cave. The cave samples were collected from filling deposits, fracture fillings, corrosion pockets, wall residues, puddles, floor detritus, clay-bearing carbonate speleothems, and fills, including those in fractures.

A detailed analysis of all samples by optical microscopy was performed to separate the mineralogical phases in each sample. The phases were analyzed by powder X-ray diffraction when the material was sufficient. Patterns were obtained on a Bruker D8 Advance X-ray diffractometer with $\mathrm{CuK} \alpha$ radiation at $40 \mathrm{kV}$ and $40 \mathrm{~mA}$, monochromated with a graphite sample monochromator. Scans were collected in the range $3-66^{\circ} 2 \theta$, with a step interval of $0.02^{\circ} 2 \theta$ and a stepcounting time of 3 seconds. Analyses of clay minerals were carried out not only on untreated samples, but also after ethylene-glycol and thermal treatments. DIFFRACplus EVA software was used to identify the mineral phases in each X-ray powder spectrum, experimental peaks being compared with 2005 PDF2 reference patterns.

Chemical composition and morphology were investigated by energy-dispersive spectroscopy with a field-emission 

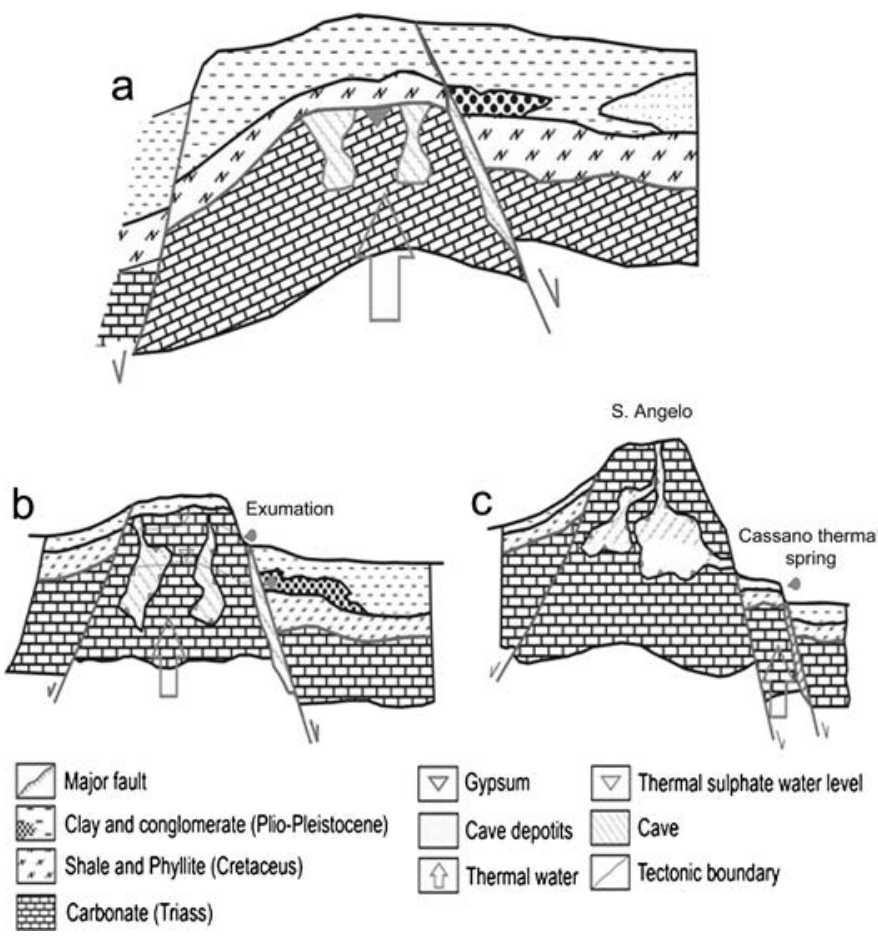

Figure 2. Sketch of the evolution of the Grotta Inferiore di Sant'Angelo, showing development in three steps: (a) development of a deep cave system by dissolution of the limestone along the major fault; (b) gradual exhumation of the top and lateral aquicludes and fall in the piezometric level; and (c) erosion and exhumation of the hanging-wall and consequent fall in the level of the thermal water.

scanning electron microscope (FEI Quanta 200). Microthermometry of fluid inclusions was conducted on a Linkam THMSG 600 heating and freezing stage coupled with a microscope equipped with $40 \times$ or $100 \times$ objectives. The stages were calibrated by a set of synthetic fluid inclusions with an estimated accuracy of about $\pm 0.1{ }^{\circ} \mathrm{C}$ at the triple point of $\mathrm{CO}_{2}\left(-56.6{ }^{\circ} \mathrm{C}\right)$, at the triple point of $\mathrm{H}_{2} \mathrm{O}(0.015$ $\left.{ }^{\circ} \mathrm{C}\right)$, and at the critical temperature of $\mathrm{H}_{2} \mathrm{O}\left(374{ }^{\circ} \mathrm{C}\right)$. The heating and cooling rate used was $0.1{ }^{\circ} \mathrm{C} \mathrm{min}^{-1}$. Spectroscopic investigations were performed by a Raman microprobe Jobin-Yvon Labram (spectral resolution $\sim 2 \mathrm{~cm}^{-1}$ ) equipped with a CCD detector and a He-Ne laser (632.8-nm emission wavelength).

\section{RESUlts}

The mineralogical study of the samples revealed ten primary minerals (Table 1); the most abundant groups were carbonates, phosphates, and sulfates. In addition to the primary minerals, enstatite, rutile, magnesite, pyrite, chrysotile, quartz, dolomite, clinochlore, and clay minerals also were found in some samples, but they are not of cave origin (Fig. 4).
Primary Mineral

\section{Carbonates}

Calcite $\left(\mathrm{CaCO}_{3}\right)$ was the most abundant mineral found in the cave, in view of the fact that the speleothems in the cave are mainly of calcitic composition. Calcite crystals are a few microns in size when growing in lanceolate aggregates (Fig. 5a), classic rhombohedral crystals (Fig. 5b), and radial aggregates of needle-like crystals diverging from the same nucleus ending in rounded surfaces, and they reached about $3 \mathrm{~mm}$ in the case of botryoidal crystals (Fig. 5c). Calcite crystals were detected in flowstones, stalagmites, and stalactites and in concretions that cover almost all the walls. The growth of calcite was controlled by evaporation and variations in $\mathrm{CO}_{2}$ concentrations in groundwater previously in contact with carbonate rocks (Holland et al., 1964; White 1976).

\section{Sulfates}

Gypsum $\left(\mathrm{CaSO}_{4} \cdot 2 \mathrm{H}_{2} \mathrm{O}\right)$ was a very common mineral, present in all thirteen samples and showing colors from milky to semi-transparent dark grey. It exhibits various morphologies: granular masses growing over corrosion pockets in the limestones of the cave walls (Fig. 5d); prismatic gypsum crystals (Fig. 5e), sometimes characterized by parallel intergrowth (Fig. 5f); lanceolate (Fig. 5g); sub-euhedral aggregate (Fig. 5h); and lamellar (Fig. 5i).

Barite $\left(\mathrm{BaSO}_{4}\right)$ occurs as globular concretions or aggregates of fibrous and lamellar crystals about $3 \mu \mathrm{m}$ in length.

In agreement with Galdenzi (1997), abundant gypsum deposits were formed as the result of oxidation of $\mathrm{H}_{2} \mathrm{~S}$-rich water during the cave origin, also confirmed by barite genesis. Gypsum crusts precipitated on the walls of the cave probably originated from water that had partially dissolved gypsum in the evaporite levels in the carbonate rocks.

\section{Phosphates}

The general name of apatite group has been given to hydroxylapatite, carbonate-hydroxylapatite, carbonatefluoropatite, and fluoropatite, because it was almost impossible to discriminate among these phosphates by stereo-microscopy or EDS microprobe analysis. The resulting morphology of these crystals of biogenetic origin in our samples is extremely variable and unusual. The largest amount occurs as a thin crust growing on a carbonrich phase that has a spongy appearance (Fig. 6a), perfect cylindrical morphology (Fig. 6b), and as microcrystals that sometimes give rise to small spheres of $10 \mu \mathrm{m}$ diameter (Fig. 6c) that may be insulated or aggregated to form thin crusts. Organic matter, verified by energy-dispersive spectroscopy, may have acted as nuclei for the crystals shown in Figure 6c. In some cases, scanning electron microscopy shows aggregates of close subparallel fibers and radial aggregates of fibrous crystals (Figs. 6d, 6e). As the literature shows, phosphates come from the reaction 


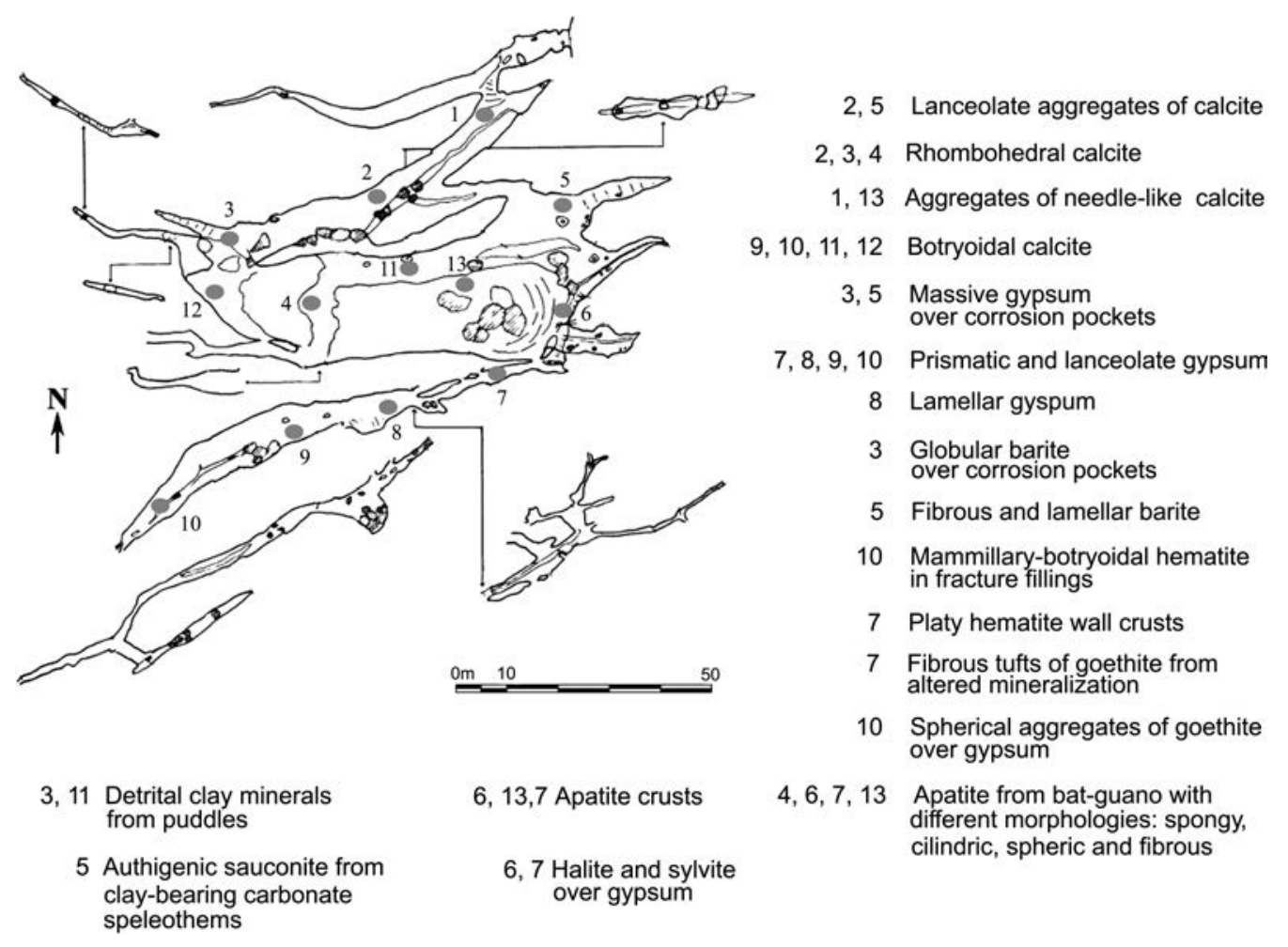

Figure 3. Plan of Grotta Inferiore di Sant'Angelo showing the location of secondary deposits sampled and the mineral occurrences observed.
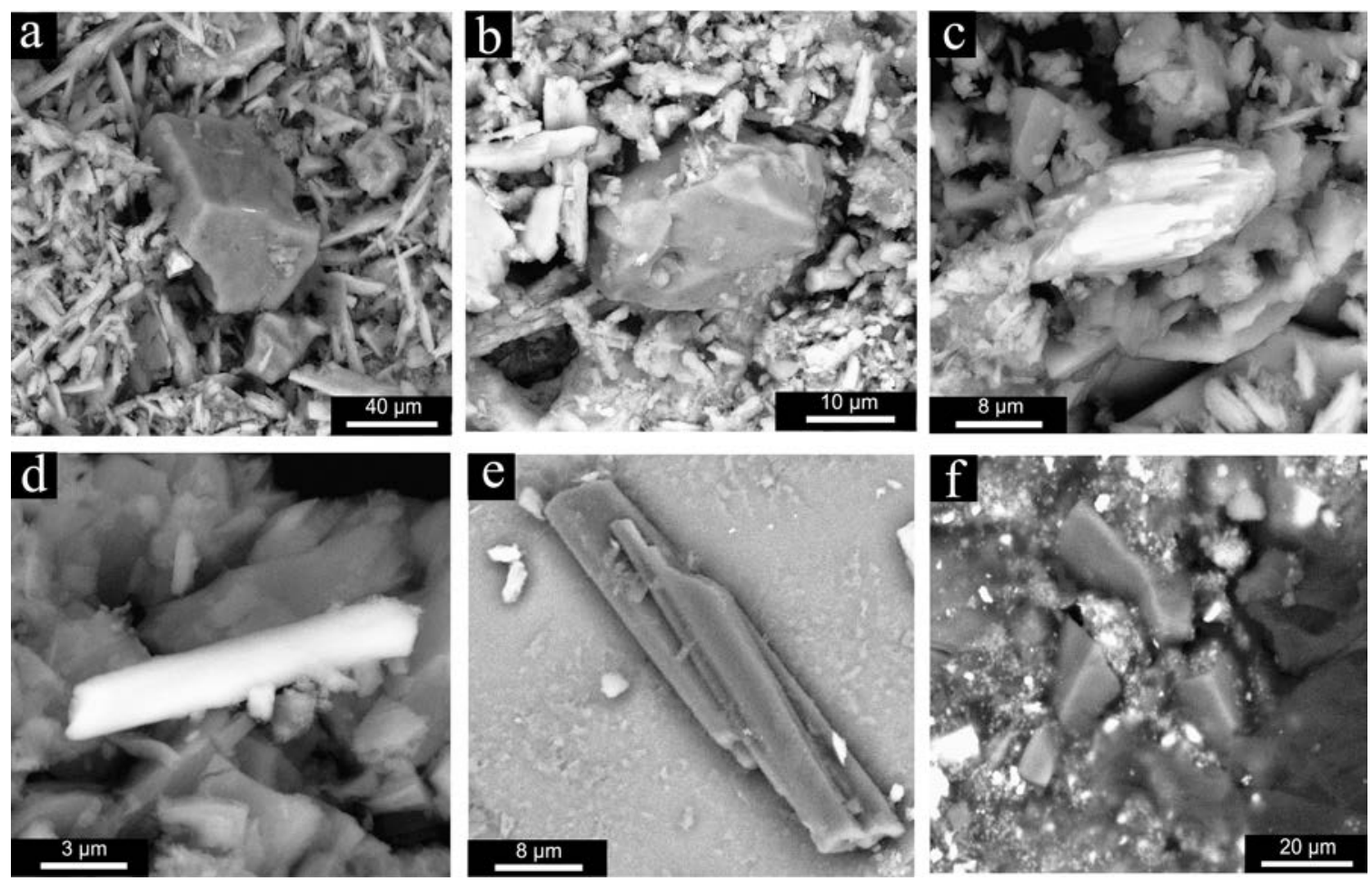

Figure 4. Scanning electron microscope images of minerals from Grotta Inferiore di Sant'Angelo: (a) subeuhedral dolomite crystals, surrounded by aggregates of calcite crystals; (b) subeuhedral quartz crystal; (c) rutile crystal; (d) chrysotile fiber; (e) elongated prismatic crystals of enstatite; (f) subeuhedral magnesite crystals. 


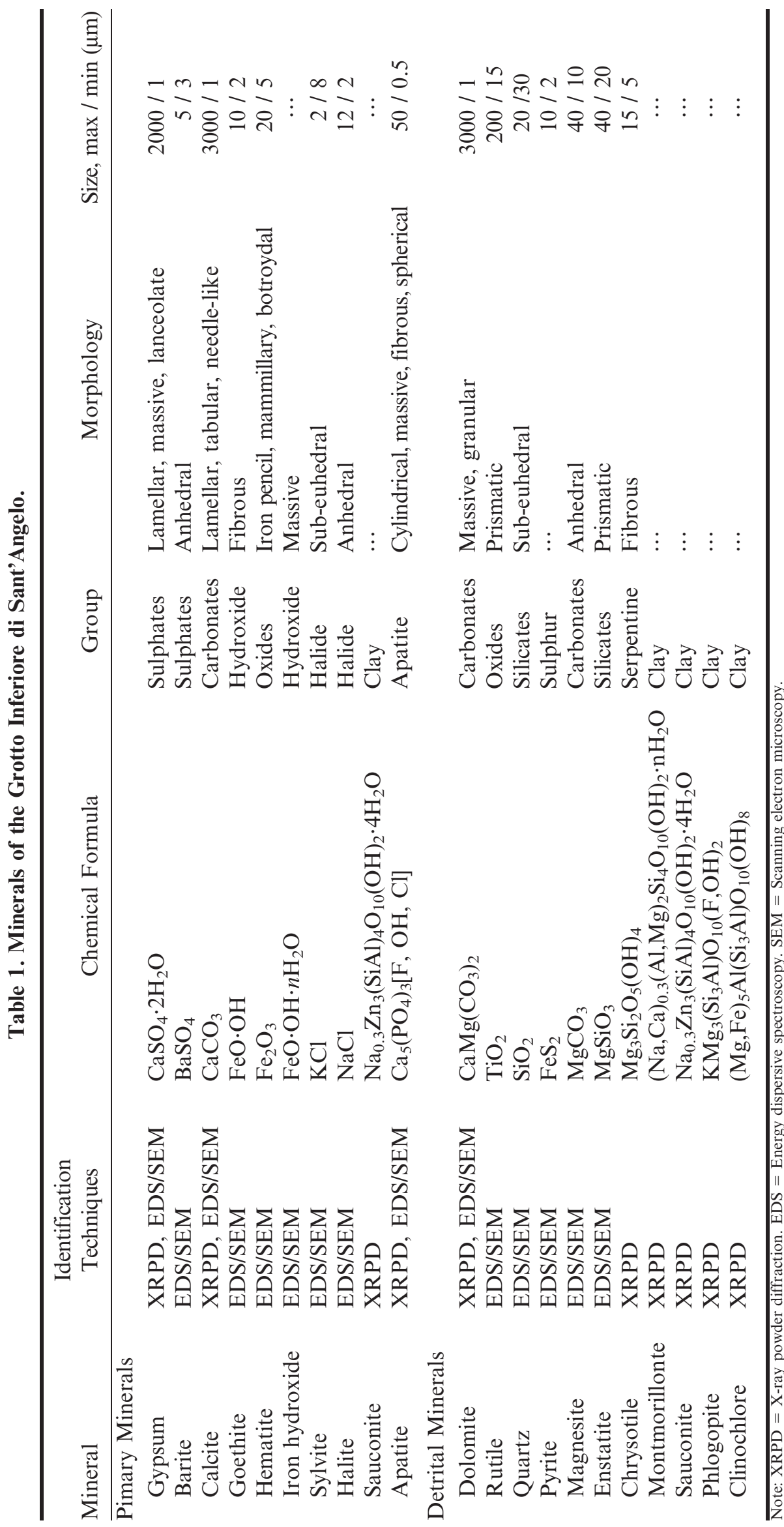

Journal of Cave and Karst Studies, April 2014•55 

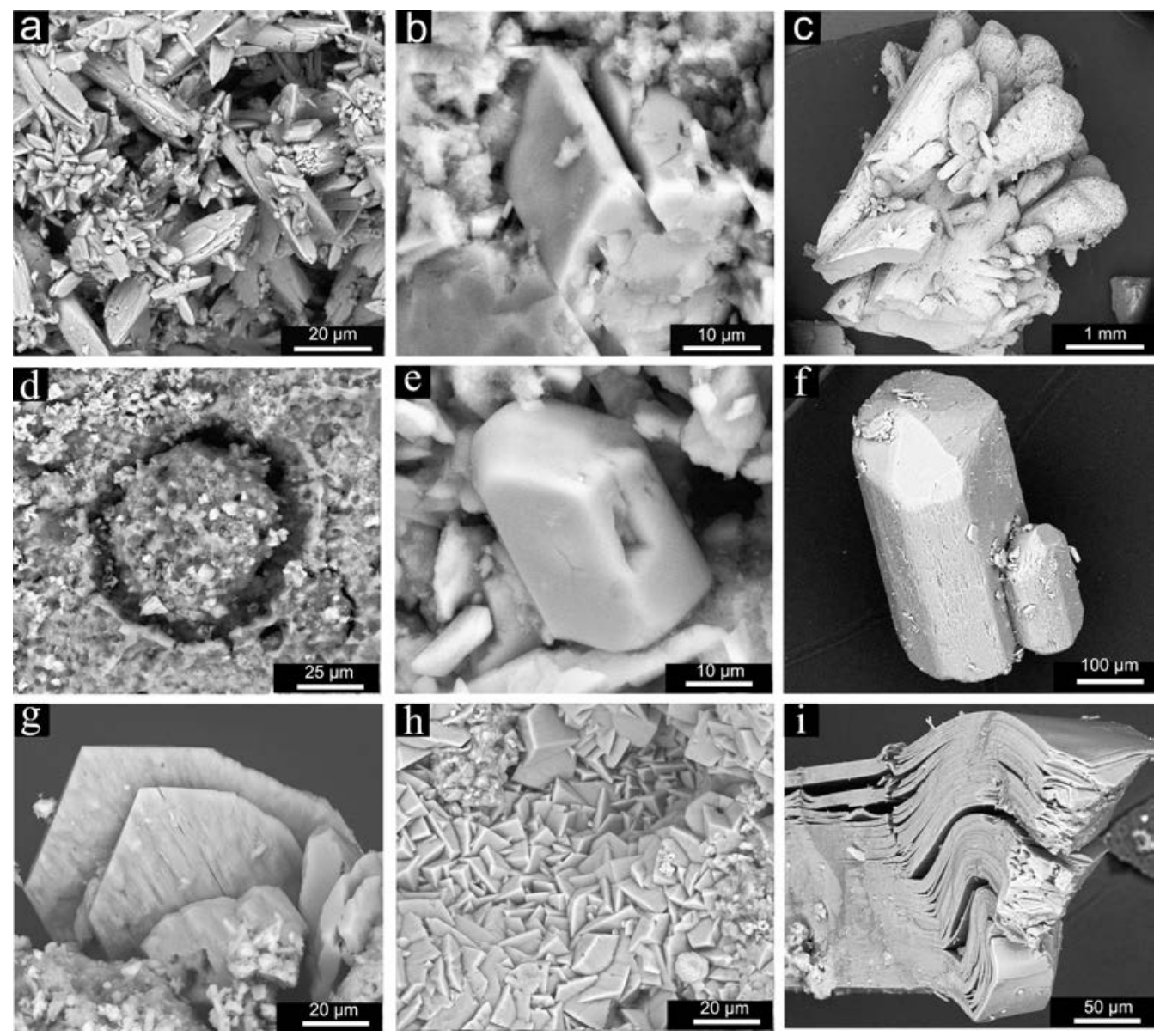

Figure 5. SEM images of minerals from Grotta Inferiore di Sant'Angelo: (a) lanceolate aggregates of calcite crystals; (b) rhombohedral calcite crystals; (c) botroydal calcite crystals; (d) massive granular gypsum; (e) prismatic euhedral gypsum crystal; (f) prismatic gypsum crystal with parallel intergrowth; (g) lanceolate gypsum crystals; (h) sub-euhedral aggregate; (i) lamellar gypsum crystals.

between calcite speleothems and phosphoric solutions derived from guano.

\section{Oxides and Hydroxides}

Iron oxide and hydroxide minerals form from the oxidation of pyrite or other iron-bearing sources (White et al., 1985; White 1988). Hematite $\left(\mathrm{Fe}_{2} \mathrm{O}_{3}\right)$ often occurs as overgrowth on gypsum crystals developed as mammillarybotryoidal aggregates (Fig. 7a) and with a platy habit (Fig. 7b). Two Fe-hydroxides phases were detected, massive amorphous iron hydroxide accumulations (Fig. 7c) and goethite $(\mathrm{FeO} \cdot \mathrm{OH})$ with small fibrous tufts and small

Table 2. Minerals identified in clay subsample $a$ before and after treating with ethylene glycol and subsample $b$ before and after heating to $450{ }^{\circ} \mathrm{C}$.

\begin{tabular}{lllll}
\hline & Subsample $a$ & & \multicolumn{2}{c}{ Subsample $b$} \\
\cline { 1 - 2 } Before & \multicolumn{1}{c}{ After } & Before & After \\
\hline Quartz & Quartz & Quartz & Quartz \\
Calcite & Calcite & & Calcite & Calcite \\
Dolomite & Dolomite & & Dolomite & Phlogopite \\
Phlogopite & Phlogopite & & Phlogopite & Chlinochlore \\
Clinochlore & Clinochlore & Clinochlore? & \\
& Sauconite & & \\
& Montmorillonite & & \\
\hline
\end{tabular}



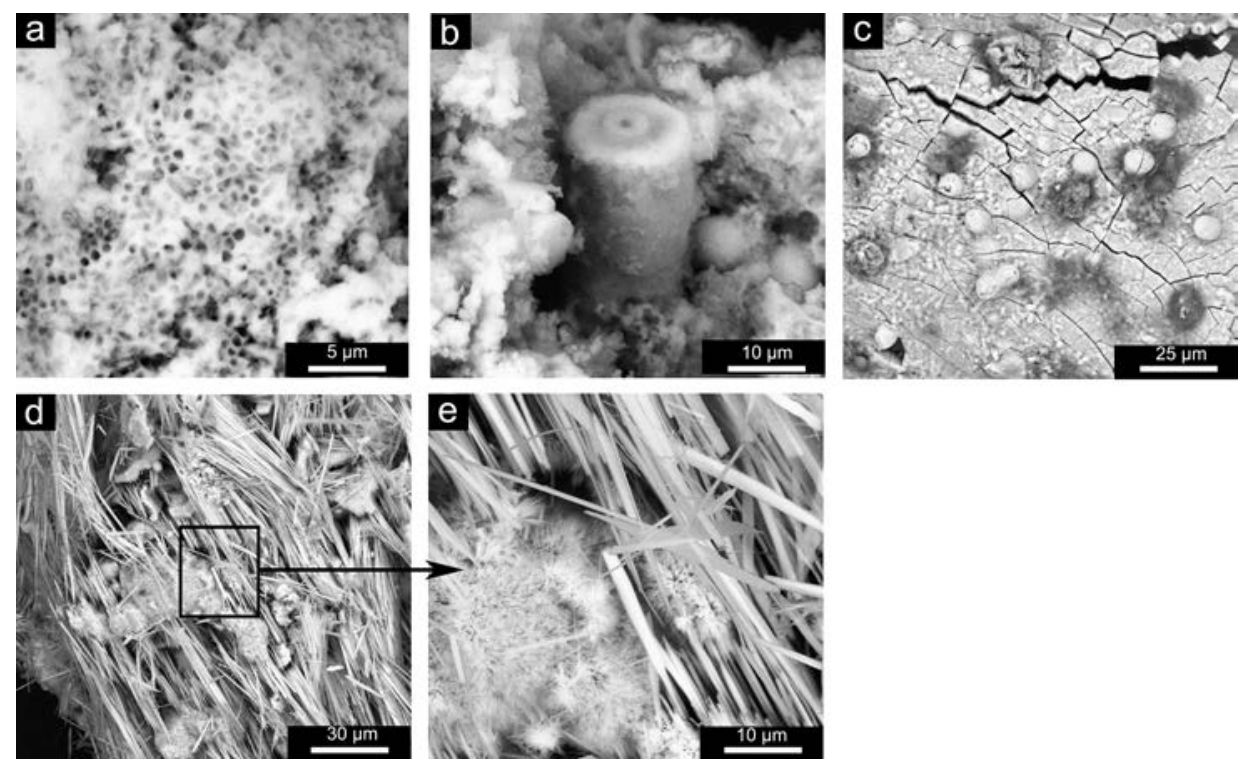

Figure 6. SEM images of minerals from Grotta Inferiore di Sant'Angelo: (a) thin crusts of apatite growing on carbon-rich phases, with spongy appearance; (b) cylindrical morphology of a single apatite crystal; (c) apatite spheres; (d) aggregates of fibrous apatite crystals; (e) magnification of image (d).

spherical aggregates growing over gypsum and calcite crystals (Fig. 7d). According to Fischer and Schwertmann (1975), although hematite and goethite phases are found together, they are not related genetically by a simple hydration-dehydration type of reaction, but were formed separately from a common source of iron. Environmental conditions play an important role in determining which of the two forms is produced (Schwertmann, 1970). Generally, higher temperatures and excess of moisture favor hematite; higher organic carbon and lower $\mathrm{pH}$ favor goethite.

\section{Halides}

Halite and sylvite (Fig. 7e), belonging to the evaporite mineral group, were also detected. They were deposited
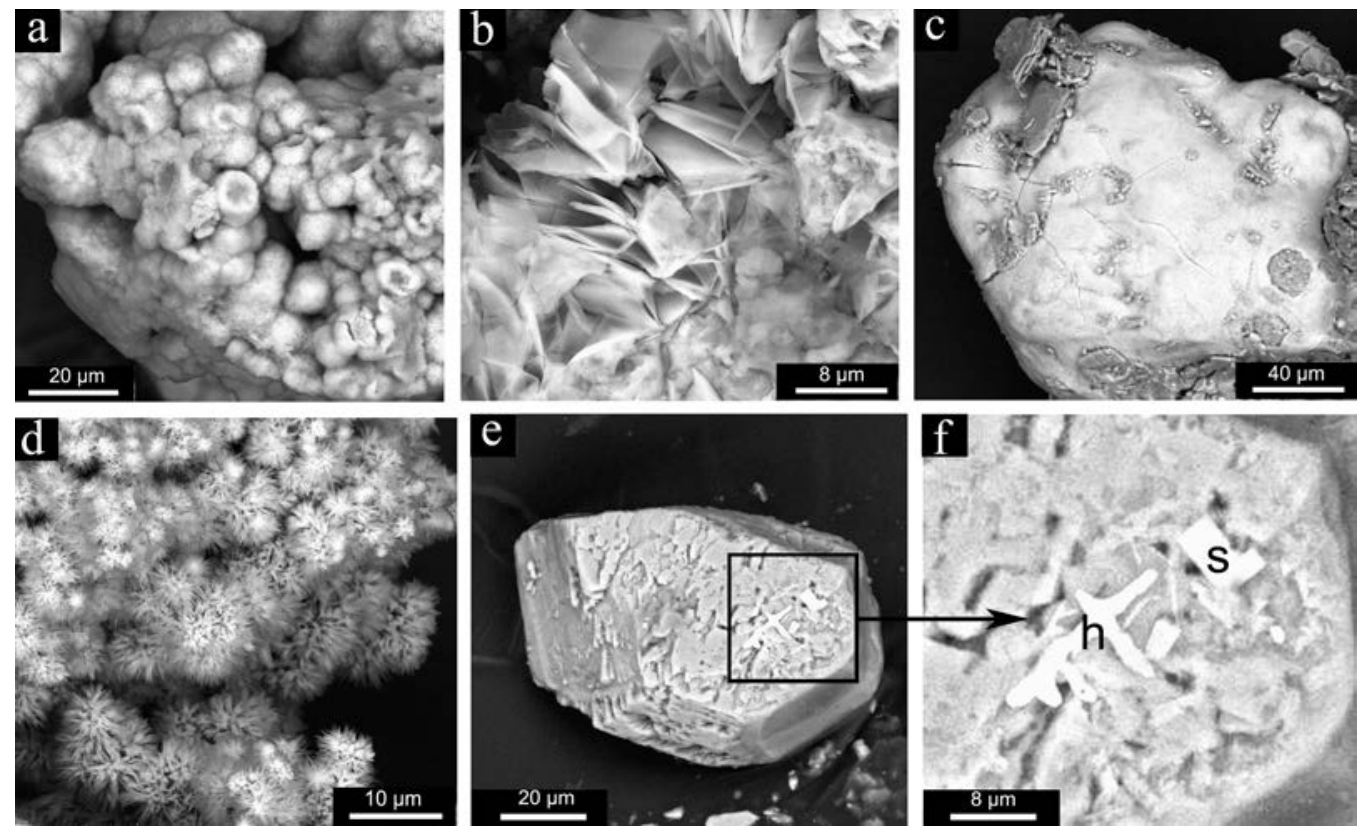

Figure 7. SEM images of minerals from Grotta Inferiore di Sant'Angelo: (a) mammillary-botroydal hematite; (b) platy hematite; (c) massive amorphous iron hydroxide; (d) fibrous tufts of goethite; (e) halite and sylvite over gypsum crystal; (f) magnification of image (e), s: sylvite, h: halite. 


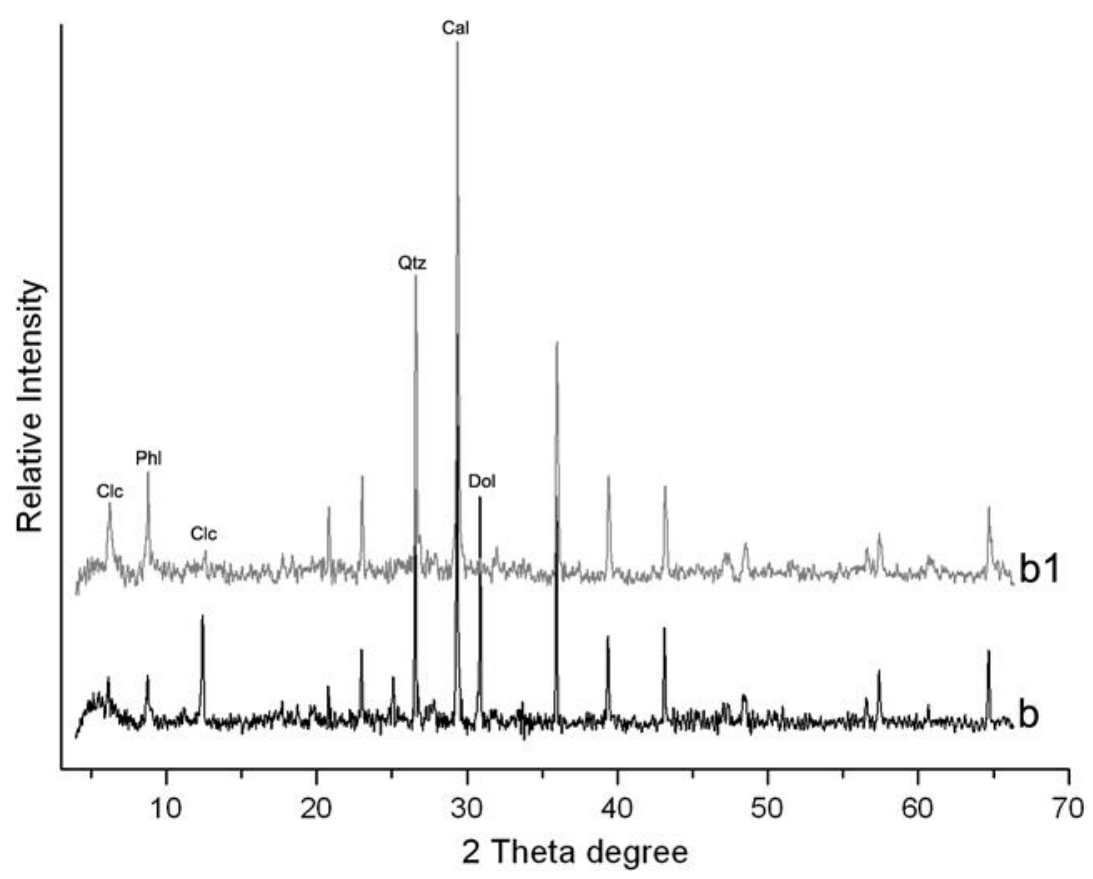

Figure 8. Powder X-ray diffraction patterns from (b) and untreated clay sample, and (b1) after heating to $450{ }^{\circ} \mathrm{C}$. Clc: clinochlore; Phl: phlogopite; Qtz: quartz; Cal: calcite; Dol: dolomite.

inside fractures in the gypsum crystals and on their surfaces. A thin film of halite (Fig. 7f) and in some cases small cubic crystals of sylvite (Fig. 7f) about $5 \mu \mathrm{m}$ in size coated the gypsum. The deposition of these evaporite minerals over the gypsum occurred during a period of strong evaporation when the cave was no longer flooded by meteoric water.

\section{Detrital Minerals}

Dolomite $\left[\mathrm{CaMg}\left(\mathrm{CO}_{3}\right)_{2}\right]$ occurs as aggregates of opaque, milky grains, sometimes massive, or large subeuhedral crystals (Fig. 4a). Crystal size ranges between $1 \mu \mathrm{m}$ and $3000 \mu \mathrm{m}$, depending on whether they are single crystals or aggregates. The origin of the dolomite is probably not related to the cave environment, because of the complex conditions that dolomite requires for its formation (Bosellini, 1991; Alonso-Zarza and Martín-Pérez, 2008) that are unlike those found in the Grotta Inferiore di Sant'Angelo. Probably dolomite was derived from the surrounding carbonate rocks.

Small pyrite $\left(\mathrm{FeS}_{2}\right)$ crystals, about $10 \mu \mathrm{m}$ in average size, were detected rarely, probably because most had been oxidized to iron oxides. Rare subeuhedral quartz $\left(\mathrm{SiO}_{2}\right)$ (Fig. 4b), found on the cave floor ranges in size from 20 to $30 \mu \mathrm{m}$ (Table 1).

Pyrite, quartz, and rutile $\left(\mathrm{TiO}_{2}\right)$, the latter identified only in two samples (Fig. 4c), are residual minerals in the weathering deposits formed on conglomerates in the area surrounding the cave and then introduced into the cave by streams or seeping waters.

Chrysotile $\left[\mathrm{Mg}_{3} \mathrm{Si}_{2} \mathrm{O}_{5}(\mathrm{OH})_{4}\right]$ of detrital origin showed the classic fibrous morphology up to $15-\mu \mathrm{m}$ long (Fig. 4d). Enstatite $\left(\mathrm{MgSiO}_{3}\right)$ was very rare, and it was identified only in one sample, with crystals of about $20 \mu \mathrm{m}$ and elongated prismatic habit (Fig. 4e). Both chrysotile and enstatite are also residual minerals derived from conglomerates. Magnesite $\left(\mathrm{MgCO}_{3}\right)$ as subeuhedral crystals of about $20 \mu \mathrm{m}$ (Fig. 4f) was found in only a few samples of detrital floor deposits. Magnesite was also occasionally present as microcrystalline, porous masses, white in color. It probably originates through metasomatism of the carbonatic rock.

\section{Clay Minerals}

One clay sample representative of the three samples collected from the puddles was divided into two parts and prepared for analysis by X-ray powder diffraction. The phases from untreated subsamples $a$ and $b$ were quartz, dolomite, calcite, clinochlore $\left[(\mathrm{Mg}, \mathrm{Fe})_{5} \mathrm{Al}\left(\mathrm{Si}_{3} \mathrm{Al}\right) \mathrm{O}_{10}(\mathrm{OH})_{8}\right]$ and phlogophite $\left[\left(\mathrm{KMg}_{3}\left(\mathrm{Si}_{3} \mathrm{Al}\right) \mathrm{O}_{10}(\mathrm{~F}, \mathrm{OH})_{2}\right]\right.$ (Table 2).

Powder X-ray diffraction patterns from the untreated clay sample $a$ (Fig. 8b) show the presence of (001) basal reflections at $14 \AA$ that could represent either montmorillonite $\left[(\mathrm{Na}, \mathrm{Ca})_{0.3}(\mathrm{Al}, \mathrm{Mg})_{2} \mathrm{Si}_{4} \mathrm{O}_{10}(\mathrm{OH})_{2} \cdot \mathrm{nH}_{2} \mathrm{O} ; \quad J C P D S\right.$ Card No. 3-0016] or clinochlore (JCPDS Card No. 120243) phases. To discriminate between them, the sample was heated to $450{ }^{\circ} \mathrm{C}$, after which the (001) basal reflection increases in intensity in the case of clinochlore, as already shown by other authors (e.g., Villieras, et al., 1994), but disappears in phases such as montmorillonite (Deer et al., 1982). Comparison between the diffraction patterns before (Fig. 8, b) and after (Fig. 8, b1) heating confirmed that the (001) basal reflection belongs to the clinochlore phase because of its increase in intensity. The (002) reflection does not disappear, as predicted by Villieras et al. (1994), 


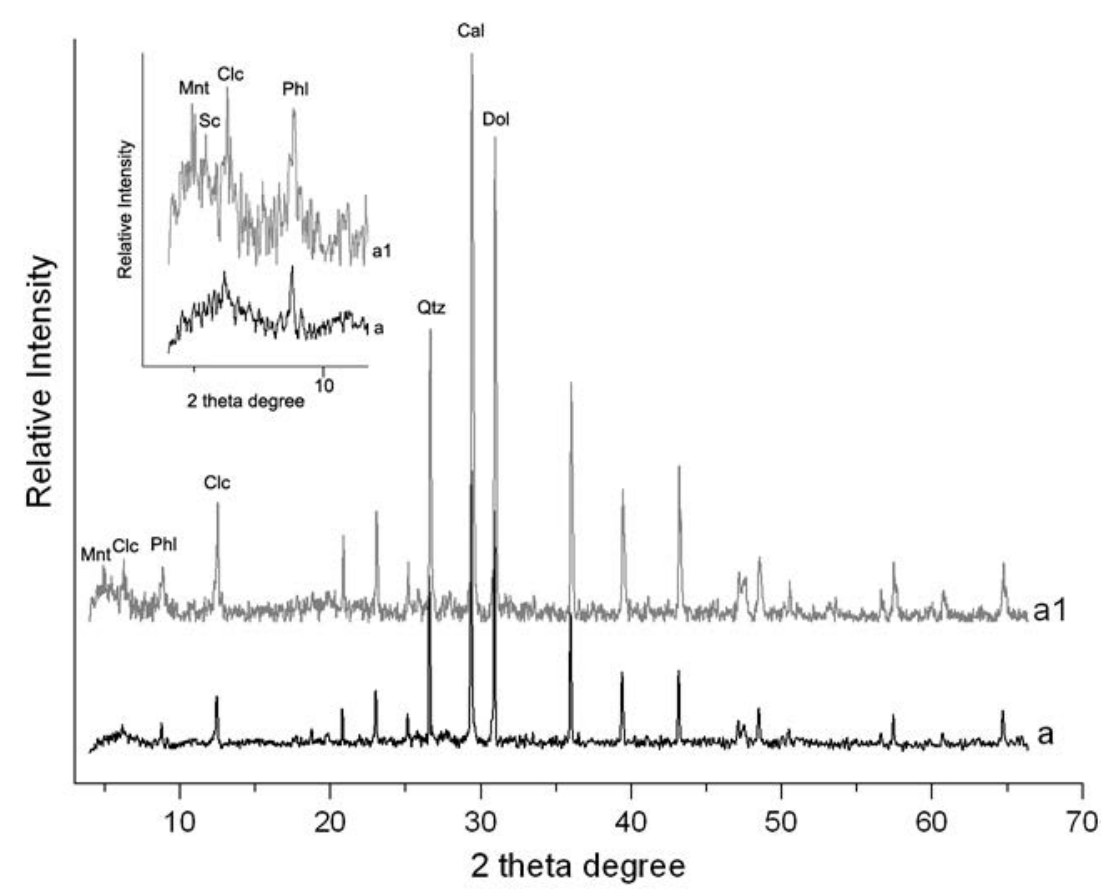

Figure 9. Powder X-ray diffraction patterns from (a) untreated clay sample and (a1) clay after ethylene-glycol treatment. Mnt: montmorillonite; Sc: sauconite; Clc: clinochlore; Phl: phlogopite; Qtz: quartz; Cal: calcite; Dol: dolomite.

but decreases in intensity, probably because structural transformation was not complete at $450{ }^{\circ} \mathrm{C}$.

Montmorillonite (JCPDS Card No. 12-0219) and sauconite $\left(\left[\mathrm{Na}_{0.3} \mathrm{Zn}_{3}(\mathrm{SiAl})_{4} \mathrm{O}_{10}(\mathrm{OH})_{2} \cdot 4 \mathrm{H}_{2} \mathrm{O}\right] ;\right.$ JCPDS Card No. 8-0255; smectite-group mineral) were found in powder diffraction patterns after saturating sample $a$ (Fig. 9, a) with ethylene glycol at $60{ }^{\circ} \mathrm{C}$ for 24 hours (Fig. 9, a1).

According to Polyak and Güven (2000a) understanding the origin of cave clays requires extensive studies, and the authigenesis of clay minerals is very hard to demonstrate. Cave sediments of detrital origin usually contain more than one clay mineral. Indeed the silicate clays observed in our samples consist of several clay phases, phlogophite, montmorillonite, sauconite, and clinochlore. The first three were probably formed through weathering of feldspars and micas derived from phyllites and conglomerates and were subsequently introduced into the cave by streams or seeping waters. The trioctahedral smectite (sauconite) found in clay-bearing carbonate speleothems could be of authigenic origin, in agreement with Polyak and Güven (2000b). Clinochlore among the clay minerals is of detrital origin, being derived from the rocks outcropping in the area around the cave.

\section{StUdy OF Gypsum InCLUSIONS}

Detailed examinations were performed on the inclusions observed in gypsum crystals. Photomicrographs illustrate the shape of the inclusions. Their size is variable, as is their shape. The inclusions show euhedral shapes, rectangular to pseudo-hexagonal, reflecting sometimes the shape of the host mineral. Their size is between 100 (Fig. 10a) and $236 \mu \mathrm{m}$ (Fig. 10b). Raman spectroscopy studies show that the inclusion contents are solid. Indeed, the spectra obtained analyzing both the surface of the gypsum crystal and the inclusions within this crystal are the same. For the gypsum, bands were observed at $407 \mathrm{~cm}^{-1}$, $492 \mathrm{~cm}^{-1}, 617 \mathrm{~cm}^{-1}, 1008 \mathrm{~cm}^{-1}, 1141 \mathrm{~cm}^{-1}$, and $3402 \mathrm{~cm}^{-1}$ (Fig. 11). This is in agreement with Frezzotti et al. (2012), and all can be also assigned to the inclusion that, for this reason, is considered as gypsum. Although both inclusion and bulk crystal are gypsum, there are some important differences. As recorded by spectra obtained by Z-scan, the ratio between water bands at $3402 \mathrm{~cm}^{-1}$ and $3506 \mathrm{~cm}^{-1}$ changes from the top to the bottom of the crystal. In particular, the ratio is 1 inside the inclusion, while above and below it, the ratio of $3402 \mathrm{~cm}^{-1}$ and $3506 \mathrm{~cm}^{-1}$ is always greater than 1 . This change in ratio can be explained by assuming that the inclusion and the crystal in which it is contained are oriented in two different directions and thus precipitated at different times. In fact, a test rotating the samples with respect to the direction of light polarization was performed and demonstrated how the different orientation of the crystals affects the intensity ratio between the various Raman bands.

Spectra obtained from the inclusion at a temperature of about $-40{ }^{\circ} \mathrm{C}$, didn't show peaks typical of ice, confirming that there probably is not liquid water in the inclusion, within the limit of detection of the Raman technique. Moreover, the inclusion does not change when cooled below $-180{ }^{\circ} \mathrm{C}$ by a stream of liquid nitrogen. 


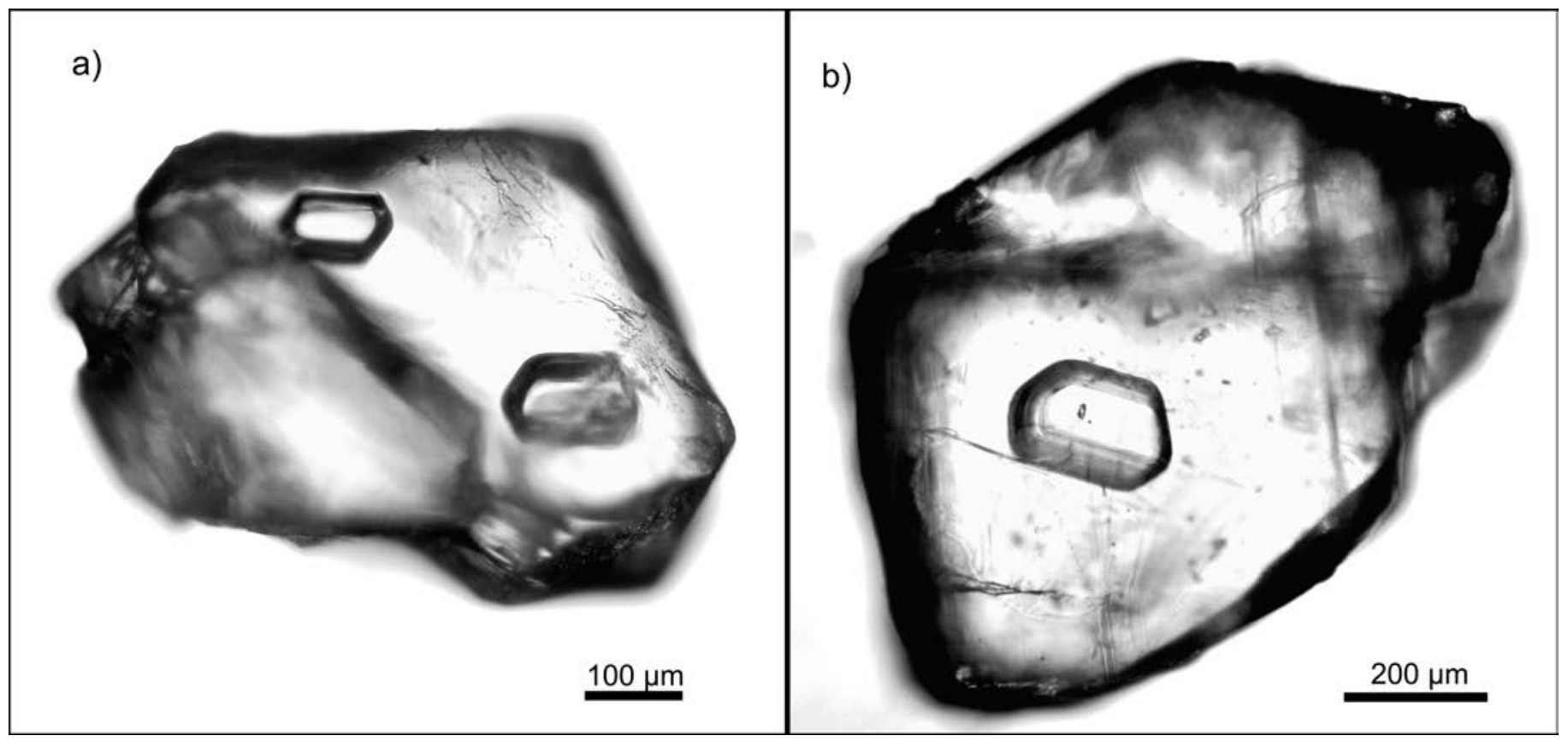

Figure 10. Photomicrographs illustrating two different sizes of solid inclusions present in gypsum crystals.

Only the very weak band at $3235 \mathrm{~cm}^{-1}$ recorded at room temperature of about $20{ }^{\circ} \mathrm{C}$ overlaps the typical spectrum of liquid water. Nevertheless, this band is sometimes also reported in spectra obtained from gypsum crystals free of inclusions and even observed in the present investigation in sample regions without liquid water. It can be assigned to a Fermi resonance of the stretching mode with an overtone of the symmetric bending vibration, both belonging to the water molecules in the gypsum crystal structure. The presence or absence of a very weak peak at

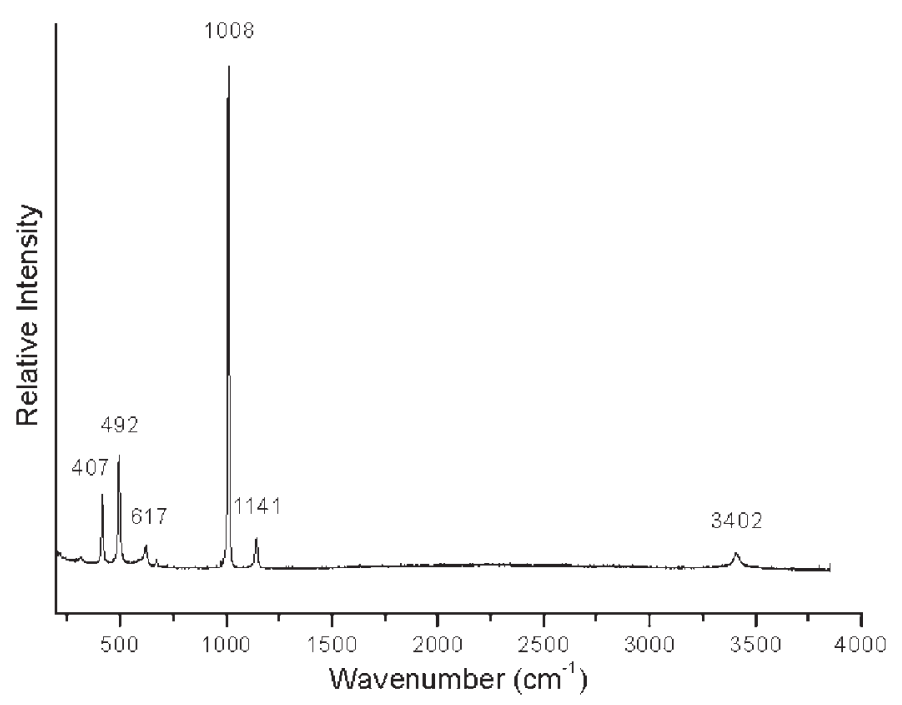

Figure 11. Representative Raman spectrum of a gypsum crystal.
$3235 \mathrm{~cm}^{-1}$ in different points of the same crystal can be due to a different orientation of it.

\section{ConClusion}

The primary minerals belonging to carbonates, sulfates, oxides and hydroxide, halides, phosphates, and silicates groups from the Grotta Inferiore di Sant'Angelo result from the interactions of cave atmosphere or water with the karst rocks and the nearby metamorphic (phyllite) and sedimentary (conglomerates) rocks. Calcite was the most abundant mineral and is very common in limestone caves, in view of the fact that the concretions (i.e., flowstones, stalagmites, and stalactites) in the cave are mainly of calcitic composition. The method of precipitation of relevant gypsum (sulfate) deposits in the cave is related to a particular water chemistry and the mineralogical characteristics of the wall rocks; indeed, sulfate waters saturated carbonate rocks and caves, enabling the precipitation and growth of sulfate crystals. Data from gypsum inclusions prove that gypsum originated in two different steps of deposition and that the secondary generation of gypsum englobed the previous one during its growth. The occurrences of hematite and goethite give valuable information about the environments in which they formed. Generally, higher temperatures and excess of moisture favor hematite, while higher organic carbon and lower $\mathrm{pH}$ favor goethite. Phosphates in the cave are scattered, and they occur in sections of the cave where bat guano supplied phosphate ions.

The presence of halite and sylvite over the gypsum is related to a period of strong evaporation when the cave 
was no longer flooded by meteoric water. Finally, trioctahedral smectite (sauconite) found in clay-bearing carbonate speleothems could be of authigenic origin. Clay minerals (phlogophite, montmorillonite and sauconite) and the detrital minerals enstatite, rutile, magnesite, pyrite, chrysotile, quartz, dolomite, and chlinoclore originated from the surrounding carbonate rocks and conglomerates.

This study presents the first data on minerals in the Grotta Inferiore di Sant'Angelo cave. Mineralogical studies in this cave cannot be considered complete. An in-depth investigation of the cave samples may reveal other mineralogical species and increase knowledge about minerogenetic changes in the cave over time.

\section{REFERENCES}

Alonso-Zarza, A.M., and Martín-Pérez, A., 2008, Dolomite in caves: Recent dolomite formation in oxic, non-sulfate environments. Castañar Cave, Spain: Sedimentary Geology, v. 205, p. 160-164. doi:10.1016/j.sedgeo.2008.02.006.

Apollaro, C., Dotsika, E., Marini, L., Barca, D., Bloise, A., De Rosa, R., Doveri, M., Lelli, M., and Muto, F., 2012, Chemical and isotopic characterization of the thermomineral water of Terme Sibarite springs (Northern Calabria, Italy): Geochemical Journal, v. 46, p. 117-129.

Benedetto, C., Forti, P., Galli, E., and Rossi, A., 1998, Chemical deposits in volcanic caves of Argentina: International Journal of Speleology, v. $27 \mathrm{~B}$, p. $155-162$.

Bosellini, A., 1991, Introduzione allo Studio delle Rocce Carbonatiche, Ferrara, Italo Bovolenta Editore, 328 p.

Deer, W.A., Howie, R.A., and Zussman, J., 1982, Rock-Forming Minerals, 2nd ed., London, Longman, 231 p.

Fischer, W.R., and Schwertmann, U., 1975, The formation of hematite from amorphous iron(III)hydroxide: Clays and Clay Minerals, v. 23, p. 33-37. doi:10.1346/CCMN.1975.0230105.

Forti, P., Galli, E., and Rossi, A., 2000, Minerali geneticamente correlati al guano in una grotta naturale dell'Albania. Primo contributo: Le Grotte d'Italia, v. 5, no. 1 , p. 45-59.

Forti, P., Galli, E., and Rossi, A., 2001, New rare cave minerals from the Perolas - Santana karst system (São Paulo State, Brazil): International Journal of Speleology, v. 29B, p. 127-150.

Forti, P., Messina, M., Papinuto, S., Sanna, F., and Sotgia, S., 1999, La più grande concrezione del mondo scoperta in una "Grotta di Miniera" del Monte San Giovanni (Iglesias): Preprint Conv. Int. "Paesaggio Minerario" Cagliari, 1, 12 p.; and Speleologia, no. 41, p. 61-68.

Frezzotti, M.L., Tecce, F., and Casagli, A., 2012, Raman spectroscopy for fluid inclusion analysis: Journal of Geochemical Exploration, v. 112, p. 1-20. doi:10.1016/j.gexplo.2011.09.009.

Frau, F., Rizzo, R., and Sabelli, C., 1998, Creedite from Sardinia, Italy: the first European occurrence: Neues Jahrbuch für MineralogieMonatshefte, v. 11, p. 495-504.
Galdenzi, S., 1997, Initial geologic observations in caves bordering the Sibari plain (southern Italy): Journal of Cave and Karst Studies, v. 59, no. 2 , p. $81-86$.

Gasparo, F., 1979, Il fenomeno carsico nel territorio comunale di Cassano allo Ionio (Provincia di Consenza): Atti e Memorie della Commissione Grotto "Eugenio Boegan,” v. 19, p. 79-116.

Hill, C.A., and Forti, P., 1997, Cave Minerals of the World, Second Edition, Huntsville, National Speleological Society, 463 p.

Holland, H.D., Kirsipu, T.W., Huebner, J.S., and Oxburgh, U.M., 1964, On some aspects of the chemical evolution of cave waters: Journal of Geology, v. 72, p. 36-67.

Larocca, F., 1991, Le Grotte della Calabria: Guida alle Maggiori Cavità Carsiche della Regione, Martina Franca, Italy, Nuova Editrice Apulia, $224 \mathrm{p}$.

Lattanzi, P., Zuddas, P., and Frau, F., 1998, Ottavite from Montevecchio, Sardinia, Italy: Mineralogical Magazine, v. 62, p. 367-370.

Malone, C., 2003, The Italian neolithic: a synthesis of research: Journal of World Prehistory, v. 17, p. 235-312. doi:10.1023/B:JOWO.0000012729. 36053.42

Orofino, F., 1965, Primo elenco catastale delle grotte della Calabria, Notiziario Circolo Speleologica Romano, no. 11, p. 15-42.

Polyak, V.J., and Güven, N., 2000a, Clays in caves of the Guadalupe Mountains, New Mexico: Journal of Cave and Karst Studies, v. 62, no. 2 , p. $120-126$.

Polyak, V.J., and Güven, N., 2000b, Authigenesis of trioctahedral smectite in magnesium-rich carbonate speleothems in Carlsbad Cavern and other caves of the Guadalupe Mountains, New Mexico: Clays and Clay Minerals, v. 48, p. 317-321.

Schiattarella, M., 1998, Quaternary tectonics of the Pollino Ridge, Calabria-Lucania boundary, southern Italy, in Holdsworth, R.E., Strachan, R.A., and Dewey, J.F., eds., Continental Transpressional and Transtensional Tectonics, Geological Society, London, Special Publication 135, p. 341-354.

Schwertmann, U., 1970, Der einfluß einfacher organischer anionen auf die bildung von goethit und hämatit aus amorphem Fe(III)-hydroxid: Geoderma, v. 3, p. 207-214. doi:10.1016/0016-7061(70)90020-0.

Spina, V., Tondi, E., Galli, P., and Mazzoli, S., 2009, Fault propagation in a seismic gap area (northern Calabria, Italy): implication for seismic hazard: Tectonophysics, v. 476, p. 357-369. doi:10.1016/j.tecto.2009.02.001.

Tinè, S., 1964a, La Grotta di Sant'Angelo III a Cassano Jonio: Atti e Memorie Società Magna Grecia, Roma, n.s., v. 5, p. 11-54.

Tinè, S., 1964b, I1 neolitico in Italia alla luce dei recenti scavi, in Atti VIII e IX Riunione Scientifica, Trieste, 19-20 Ottobre 1963, Calabria, 6-8 Aprile 1964, Firenze, Istituto Italiano di Preistoria e Protostoria, p. $277-289$.

Villieras, F., Yvon, J., Cases, J.M., De Donato, P., Lhote, F., and Baeza, R., 1994, Development of microporosity in cliochlore upon heating: Clays and Clay Minerals, v. 42, p. 679-688.

White, W.B., 1976, Cave minerals and speleothems, in Ford, T.D., and Cullingford, C.H.D., eds., The Science of Speleology: London, Academic Press, 593 p.

White, W.B., Scheetz, B.E., Atkinson, S.D., Ibberson, D., and Chess, C.A., 1985, Mineralogy of Rohrer's Cave, Lancanster County, Pennsylvania: Bulletin of the National Speleological Society, v. 47, p. 17-27.

White, W.B., 1988, Geomorphology and Hydrology of Karst Terrains, New York, Oxford University Press, 464 p. 